\title{
PERSEKUSI DALAM TINJAUAN FIQH JINAYAH
}

\author{
Hanif Azhar \\ STAI Hasan Jufri Bawean \\ Email: hanif.azhar15@gmail.com
}

\begin{abstract}
Persecution according to the original meaning is a crime against humanity. Violations of human rights. Even some forms of persecution are classified as genocide. In its development, the use of the word perskusi in Indonesia in cases of coercion, ill-treatment, beatings and so on that occurred in the last three years is considered inappropriate and too excessive. Based on the pattern of criminal acts that occur what is referred to as persecution is actually an act of vigilante who in the criminal law system in Indonesia has been known as eigenrechting. Based on the pattern also, the most common criminal element in the act of vigilantism is entering someone else's house without permission, coercion, kidnapping, torture, and beatings. In the fiqh jinayah review, this crime is also classified into several categories of jarimah. The coercive and kidnapping crimes are classified as Jarimah Hirabah. Persecution and beatings belong to jarimah al-jurh. While entering someone else's house, it is Jarimah Ta'zir.
\end{abstract}

Keywords: persecution, vigilantism, jinayah fiqh

\begin{abstract}
Abstrak
Persekusi menurut makna asalnya merupakan suatu kejahatan terhadap kemanusiaan. Pelanggaran terhadap hak asasi manusia. Bahkan beberapa bentuk tindakan persekusi tergolong sebagai genosida. Dalam perkembangannya, penggunaan kata perskusi di Indonesia terhadap kasus-kasus pemaksaan, penganiayaan, pengeroyokan dan sebagainya yang marak terjadi tiga tahun terakhir ini dianggap kurang tepat dan terlalu berlebihan. Berdasarkan pola tindak pidana yang terjadi apa yang sebut sebagai persekusi sebenarnya adalah tindakan main hakim sendiri yang dalam tata hukum pidana di Indonesia telah dikenal dengan sebutan eigenrechting. Berdasarkan polanya pula, unsur pidana yang paling sering terjadi dalam tindakan main hakim sendiri (perskusi) ialah memasuki rumah orang lain tanpa izin, pemaksaan, penculikan, penganiayaan, dan pengeroyokan. Dalam tinjauan fiqh jinayah, tindak pidana ini juga tergolong dalam beberapa kategori jarimah. Tindak pidana pemaksaan dan penculikan tergolong ke dalam jarimah hirabah. Penganiayaan dan pengeroyokan tergolong ke dalam jairmah al-jurh. Sementara memasuki rumah orang lain tergolong jarimah ta'zir.
\end{abstract}

Kata kunci: persekusi, main hakim sendiri, fiqh jinayah

\section{PENDAHULUAN}

Istilah persekusi mulai viral di Indonesia sejak awal tahun 2017. Hingga kini istilah ini masih menjadi perdebatan di berbagai kalangan, seperti tokoh nasional, akademisi dan LSM. Tindakan persekusi merujuk pada suatu tindakan dimana seseorang atau sekelompok orang yang merasa tidak suka dan menuduh pihak lain telah melakukan kesalahan (pelanggaran atau kejahatan) kemudian mereka melakukan tindakan sendiri 
untuk "menghakimi" pihak lain itu. Tindakan ini tampak dalam berbagai bentuk, seperti mencaci, pemukulan, penganiayaan, perusakan hingga terbunuhnya korban.

Banyak kalangan, diantaranya Aryojati Ardipandanto ${ }^{1}$, menyinyalir merebaknya kasus persekusi di tanah air diawali dengan kehebohan kasus penistaan agama yang dituduhkan kepada Gubernur DKI Jakarta Basuki Tjahaya Purnama Atau Ahok. Semenjak kasus ini, bermunculanlah kasus-kasus persekusi yang cenderung meningkat dari waktu-ke waktu.

Sebagaimana disampaikan oleh Trias Palupi Kurnianingrum² kasus-kasus itu diantaranya berlangsung pada bulan Mei 2017. Terjadi kasus persekusi dimana sekelompok masa menggeruduk korban. Pemicunya ialah postingan di akun media sosial milik korban yang dianggap melecehkan pihak tertentu. Kasus ini menimpa seorang dokter di RSUD Kota Solok Sumatra Barat dan seorang remaja di Cipinang Muara Jakarta Timur. Pada bulan Agustus, seorang korban meninggal dihakimi masa akibat dituduh mencuri amplifier sebuah musalla. Pada bulan November, sepasang kekasih dipersekusi dengan tuduhan berbuat mesum. Kasus-kasus serupa masih terus bermunculan hingga kini. Beragam bentuk tindakan ini tidak dapat dibenarkan secara hukum karena dilakukan di luar koridor hukum dan tidak pula dilakukan oleh aparat penegak hukum.

Berbagai tindakan telah banyak dikaji dari berbagai sisi, seperti politik dan hukum. Dalam tulisan ini, persekusi akan dikaji dari perspektif fiqh jinayah atau Hukum Pidana Islam.

\section{PENGERTIAN PERSEKUSI}

Persekusi merupakan kata benda. Serapan dari bahasa inggris (n) persecution. Yang diserap dari bahasa Prancis persecuter. Dari bahasa latin persecut. ${ }^{3}$ Dalam bahasa Inggris, Kamus Oxford mengartikan kata persecution (n) dengan: Hostility and illtreatment, especially because of race or political or religious beliefs; oppression

\footnotetext{
1 Aryojati Ardipandanto, Persekusi; Perspektif Demokrasi, Majalah Info Singkat, Pemerintahan Dalam Negeri, Vol. IX, No. 11, Juni 2017 (Jakarta: Pusat Penelitian Badan Keahlian DPR RI, 2017), $17-18$.

2 Trias Palupi Kurnianingrum, Pengertian Persekusi dari Perspektif Hukum, Majalah Info Singkat, Hukum, Vol. IX, No. 24, Desember 2017 (Jakarta: Pusat Penelitian Badan Keahlian DPR RI, 2017), 1-2.

${ }^{3} \mathrm{https}: / / w w w . l e x i c o . c o m / e n /$ definition/persecute. Diakses pada tanggal 16 Mei 2019.
} 
(Permusuhan dan perlakuan buruk, terutama karena ras atau keyakinan politik atau agama; penindasan). ${ }^{4}$ Kata kerjanya persecute (v). Diartikan: Subject (someone) to hostility and ill-treatment, especially because of their race or political or religious beliefs (menundukkan atau menaklukkan (seseorang) pada permusuhan dan perlakuan buruk, terutama karena ras atau keyakinan politik atau agama mereka).

Sementara Kamus Merriam Webster mengartikan persecution (n) sebagai: the act or practice of persecuting especially those who differ in origin, religion, or social outlook (tindakan atau praktik penganiayaan terutama pada mereka yang berbeda dalam hal asal, agama, atau pandangan sosial). ${ }^{5}$ Sementara perecute $(v)$ : to harass or punish in a manner designed to injure, grieve, or afflict specifically : to cause to suffer because of belief (untuk melecehkan atau menghukum dengan cara yang dirancang untuk melukai, berduka, atau menindas khususnya agar menyebabkan menderita karena kepercayaan). ${ }^{6}$

Dalam Kamus Longman persecution (n): cruel or unfair treatment of someone over a period of time, especially because of their religious or political beliefs (perlakuan kejam atau tidak adil terhadap seseorang selama periode waktu tertentu, terutama karena kepercayaan agama atau politik mereka). ${ }^{7}$ Sementara perecute $(v)$ : (1) to treat someone cruelly or unfairly over a period of time, especially because of their religious or political beliefs (untuk memperlakukan seseorang dengan kejam atau tidak adil selama periode waktu tertentu, terutama karena kepercayaan agama atau politik mereka); (2) to deliberately cause difficulties for someone by annoying them often (sengaja menyebabkan kesulitan bagi seseorang dengan sering mengganggu mereka). ${ }^{8}$

Dalam bahasa Arab kata persekusi diterjemahkan dengan إضطهاد. Kamus Almaany mengartikannya dengan:

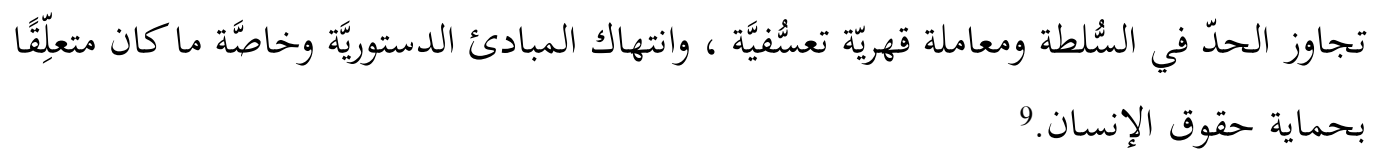

\footnotetext{
${ }^{4} \mathrm{https} / / / \mathrm{www}$. lexico.com/en/definition/persecution. Diakses pada tanggal 16 Mei 2019.

${ }^{5} \mathrm{https}$ //Www.merriam-webster.com/dictionary/persecution. Diakses pada tanggal 16 Mei 2019.

${ }^{6} \mathrm{https}: / / \mathrm{www} . \mathrm{merriam}-\mathrm{webster} . c 0 \mathrm{~m} /$ dictionary/persecute. Diakses pada tanggal 16 Mei 2019.

${ }^{7} \mathrm{https} / / / \mathrm{www}$. ldoceonline.com/dictionary/persecution, diakses pada tanggal 18 Mei 2019.

${ }^{8} \mathrm{https}$ ://www.ldoceonline.com/dictionary/persecute, diakses pada tanggal 18 Mei 2019.

9 https://www.almaany.com/ar/dict/ar-ar/اضطهاد/, diakses pada tanggal 18 Mei 2019
} 
(Melampaui batas [dalam] kekuasaan dan perlakuan paksa, sewenang-wenang, melanggar prinsip-prinsip konstitusional, terutama perlindungan Hak Asasi Manusia).

Dalam versi aplikasi, Arab-Indonesia, kata إضطهاد diartikan dengan: penindasan; pemaksaan. Sementara memersekusi (إضََََْْ) diartikan:

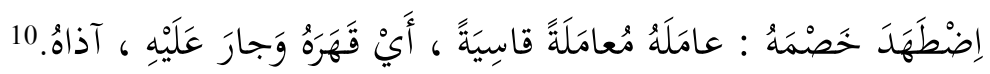

(Memperlakukan dengan kasar; memaksa dan menganiaya; menyakiti).

Lalu dalam Kamus Besar Bahasa Indonesia (KBBI) persekusi diartikan sebagai perburuan sewenang-wenang terhadap seseorang atau sejumlah warga yang kemudian disakiti, dipersusah atau ditumpas. ${ }^{11}$ Sementara kata kerjanya memersekusi. Berarti menyiksa atau menganiaya. ${ }^{12}$

Dari berbagai definisi ini dapat disimpulkan bahwa persekusi merupakan suatu tindak pidana yang tidak tunggal. Ia muncul dalam berbagai bentuk. Mulai dari perlakuan buruk, intimidasi, penganiayaan bahkan pembunuhan. Yang perlu digarisbawahi ialah bahwa persekusi umumnya terkait dengan perbedaan ras, politik dan agama atau keyakinan.

\section{PERSEKUSI MENURUT HUKUM INTERNASIONAL}

Apa yang disebut sebagai persekusi merupakan tindakan kejahatan terhadap kemanusiaan dalam berbagai dokumen hukum internasional. Diantaranya secara implisit tercantum dalam Convention on the Prevention and Punishment of the Crime of Genocide (Konvensi tentang Pencegahan dan Hukuman Kejahatan atas Genosida) atau Konvensi Genosida tahun 1948 pasal 2 yang menyebutkan bahwa yang disebut genosida ialah: tindakan dengan maksud menghancurkan, keseluruhan atau sebagian, kelompok agama, ras, etnis atau kebangsaan dengan cara (a) membunuh, (b) merusak fisik atau

\footnotetext{
${ }^{10}$ Ibid.

${ }^{11} \mathrm{https} / / /$ kbbi.kemdikbud.go.id/entri/persekusi, diakses pada tanggal 18 Mei 2019

$12 \mathrm{https} / / / \mathrm{kbbi}$.kemdikbud.go.id/entri/memersekusi, diakses pada tanggal 18 Mei 2019
} 
mental (c) penghancuran fisik; (d) mencegah kelahiran, (e) memindahkan anak-anak dari satu kelompok ke kelompok lain. ${ }^{13}$

Dalam Statute Of The International Criminal Tribunal For The Former Yugoslavia (Statuta Pengadilan Kriminal Internasional untuk Bekas Yugoslavia) atau ICTY tahun 1993 Pasal 5 tentang Kejahatan terhadap Kemanusiaan disebut kan berbagai tindakan yang tergolong sebagai kejahatan kemanusiaan, yaitu: (a) pembunuhan, (b) pemusnahan, (c) perbudakan, (d) deportasi, (e) penjara, (f) penyiksaan, (g) pemerkosaan, (h) penganiayaan karena alasan politik, ras dan agama, (i) tindakan tidak manusiawi lainnya. ${ }^{14}$ Redaksi yang kurang lebih sama juga disebutkan dalam Statute Of The International Tribunal For Rwanda (Statuta Pengadilan Internasional Untuk Rwanda) Atau ICTR tahun 1994 Pasal 3 tentang Kejahatan terhadap Kemanusiaan. ${ }^{15}$ Secara eksplisit, menurut David Cohen, ahli hukum internasional dari Stanford University Amerika Serikat, persekusi telah diakui sebagai tindakan kejahatan terhadap kemanusiaan secara internasional sejak diadopsinya ICTY tahun 1993 dan ICTR tahun 1994 ini. Dalam dua statuta ini persekusi mencakup semua tindakan pembatasan hakhak dasar dengan unsur diskriminatif berdasarkan ras, politik, atau agama. ${ }^{16}$

Dalam Rome Statute Of The International Criminal Court (Statuta Roma tentang Pengadilan Pidana Internasional) atau Statuta Roma tahun 1998 Pasal 7 ayat 1 huruf $\mathrm{h}$ tentang Kejahatan terhadap Kemanusiaan disebutkan bahwa mahkamah berwenang untuk mengadili tindakan: (h) Penganiayaan (persekusi) terhadap kelompok apa pun yang berkaitan dengan identitas politik, ras, kebangsaan, etnis, budaya, agama, jenis kelamin sebagaimana disebutkan dalam ayat 3, atau alasan lain yang secara universal diakui dilarang berdasarkan hukum internasional. Penjelasan huruf ini menyebutkan bahwa persekusi berarti perampasan hak-hak fundamental yang disengaja dan serius yang bertentangan dengan hukum internasional dengan alasan identitas kelompok. Menurut David Cohen, dengan pasal 7 Statuta Roma ini, terutama

\footnotetext{
13 https://www.un.org/en/genocideprevention/genocide-convention.shtml, diakses pada tanggal 19 Mei 2019.

14 http://www.icty.org/x/file/Legal\%20Library/Statute/statute_sept09_en.pdf, diakses pada tanggal 19 Mei 2019.

15 http://legal.un.org/avl/pdf/ha/ictr_EF.pdf, diakses pada tanggal 19 Mei 2019.

16 https://ylbhi.or.id/informasi/kegiatan/persekusi-dalam-kerangka-hukum-internasional/, diakses pada tanggal 19 Mei 2019.
} 
penjelasannya, cakupan makna persekusi menjadi semakin luas. Semula hanya mencakup semua tindakan pembatasan hak-hak dasar dengan unsur diskriminatif berdasarkan ras, politik, atau agama menjadi mencakup semua tindakan perampasan hak-hak fundamental yang disengaja dan serius yang bertentangan dengan hukum internasional berdasarkan identitas kelompok ${ }^{17}$ Ia menambahkan, untuk dapat dikatakan sebagai kejahatan kemanusiaan, persekusi harus dilakukan dalam konteks serangan meluas atau sistematik terhadap penduduk sipil dengan maksud mendiskriminasi yang didasari perbedaan ras, politik atau agama. ${ }^{18}$

Dari berbagai statuta internasional ini dapat disimpulkan bahwa yang dimaksud dengan persekusi dalam hukum internasional ialah segala bentuk kejahatan dengan maksud mendiskriminasi yang dilakukan secara meluas dan sistematis terhadap suatu kelompok (penduduk sipil) atas dasar politik, ras, kebangsaan, etnis, budaya, agama, dan gender, yang tidak diperbolehkan berdasarkan hukum internasional.

Menurut Iwan Setiawan persekusi merupakan suatu istilah hukum yang khas dan spesifik dalam kaitannya dengan perlindungan hak asasi manusia (HAM) serta dalam situasi yang khusus pula, yakni manakala mekanisme perlindungan nasional tidak tersedia. ${ }^{19}$

\section{PERSEKUSI DI INDONESIA}

Kejahatan terhadap kemanusiaan diatur dalam Undang-undang No. 26 tahun 2000 tentang Pengadilan Hak Asasi Manusia. UU ini telah mengadopsi konsep pengaturan mengenai pengadilan HAM dari konsep internasional yang telah ada. Pasal 9 UU ini menyebutkan:

Kejahatan terhadap kemanusiaan sebagaimana dimaksud dalam Pasal 7 huruf b adalah salah satu perbuatan yang dilakukan sebagai bagian dari serangan yang meluas atau sistematik yang diketahuinya bahwa serangan tersebut ditujukan secara langsung terhadap penduduk sipil, berupa: a. pembunuhan; b. pemusnahan; c. perbudakan; d. pengusiran atau pemindahan penduduk secara paksa; e.

\footnotetext{
17 Ibid.

18 Ibid.

19 Iwan Setiawan, Kajian Yuridis Terhadap Persekusi, Jurnal Ilmiah Galuh Yustisi, Vol. 5 No. 2, September 2017 (Ciamis: Fakultas Hukum Universitas Galuh), 295.
} 
perampasan kemerdekaan atau perampasan kebebasan fisik lain secara sewenangwenang yang melanggar (asas-asas) ketentuan pokok hukum internasional; f. penyiksaan; g. perkosaan, perbudakan seksual, pelacuran secara paksa, pemaksaan kehamilan, pemandulan atau sterilisasi secara paksa atau bentukbentuk kekerasan seksual lain yang setara; $h$. penganiayaan terhadap suatu kelompok tertentu atau perkumpulan yang didasari persamaan paham politik, ras, kebangsaan, etnis, budaya, agama, jenis kelamin atau alasan lain yang telah diakui secara universal sebagai hal yang dilarang menurut hukum internasional; i. penghilangan orang secara paksa; atau j. kejahatan apartheid.

Dalam UU HAM tidak ditemukan kata persekusi. UU ini justru mencantumkan kata lain yang semaksud dengan itu sebagaimana disebut dalam klasifikasi pada huruf $h$, yaitu penganiayaan. Demikian pula dalam berbagai perundangan lain seperti KUHP. Tidak satupun yang secara eksplisit mencantumkan kata persekusi. Jadi kesimpulannya istilah persekusi tidak dikenal dalam perundang-undangan di Indonesia.

Telah dijelaskan di muka bahwa apa yang dimaksud dengan persekusi dalam hukum internasional dengan apa yang dimaksud persekusi dalam praktiknya di Indonesia, dalam batas tertentu, tidaklah sama. Premis ini akan dimulai pertama, dari definisi persekusi dalam KBBI. Persekusi diartikan sebagai perburuan sewenang-wenang terhadap seseorang atau sejumlah warga yang kemudian disakiti, dipersusah atau ditumpas. ${ }^{20}$ Kata kerjanya memersekusi diartikan dengan menyiksa atau menganiaya. ${ }^{21}$ Yang perlu digarisbawahi ialah kata perburuan. Berburuan sewenang-wenang. Perburuan mengandung pengertian mengejar, memburu dengan tujuan menangkap dan memperlakukan target dengan perlakuan tertentu. Sewenang-wenang berarti dengan tidak mengindahkan hak orang lain; dengan semau-maunya; dengan kuasa sendiri. ${ }^{22}$ Kedua, dari berbagai laporan media tentang praktik persekusi di Indonesia. Dari dua premis ini didapati gambaran tentang apa yang sementara masyarakat anggap sebagai persekusi.

\footnotetext{
${ }^{20} \mathrm{https} / / /$ kbbi.kemdikbud.go.id/entri/persekusi, diakses pada tanggal 19 Mei 2019.

${ }^{21} \mathrm{https} / / / \mathrm{kbbi}$.kemdikbud.go.id/entri/memersekusi, diakses pada tanggal 19 Mei 2019.

$22 \mathrm{https} / / / \mathrm{kbbi}$.kemdikbud.go.id/entri/sewenang-wenang, diakses pada tanggal 19 Mei 2019.
} 
Nur Pujayanti dan Harry Soeskandi dalam penelitiannya merangkum berbagai kasus persekusi yang dimuat di media masa dan menyimpulkan berdasarkan pola umum bahwa apa yang oleh masyarakat disebut sebagai persekusi sebenarnya ialah tindakan main hakim sendiri yang dalam tata hukum Indonesia sudah dikenal dengan istilah eigenrechting. Jika bukan, setidaknya itu adalah bentuk baru dari tindakan main hakim sendiri. 23

Dalam penelitiannya yang lain Nur Pujayanti menambahkan bahwa memang sebenarnya ada perbedaan antara persekusi dengan tindakan main hakim sendiri. Hal ini dilihat dari dua hal, yaitu dari proses tindakan dan motifnya. Berdasarkan proses tindakannya, persekusi diawali dengan mencari dan menemukan target baru kemudian dilakukan eksekusi. Sedangkan main hakim sendiri, lebih sering terjadi dalam hal tertuduh tertangkap tangan atau dalam keadaan terpaksa. Berdasarkan motifnya, persekusi umumnya didasarkan atas alasan politik, ras, kebangsaan, etnis, budaya, agama atau gender. Sementara main hakim sendiri, secara terbatas, dilakukan untuk membela diri. Namun demikian, persekusi dan main hakim sendiri memiliki persamaan. Pertama, sama-sama dilakukan terhadap terduga pelaku tindak pidana. Kedua, samasama dilakukan tanpa melalui proses atau prosedur hukum yang semestinya. ${ }^{24}$

Berpijak dari kesimpulan ini, pembahasan selanjutnya tentang persekusi dalam tulisan ini akan mengacu pada kerangka ini.

KBBI mengartikan main hakim sendiri dengan menghakimi orang lain tanpa memedulikan hukum yang ada (biasanya dilakukan dengan pemukulan, penyiksaan, pembakaran, dan sebagainya). ${ }^{25}$ Kamus Hukum Sindikat mengartikan main hakim sendiri dengan tindakan untuk melaksanakan hak menurut kehendak sendiri tidak lain merupakan tindakan untuk melaksanakan hak menurut kehendak sendiri yang bersifat sewenang-wenang, tanpa persetujuan pihak lain yang berkepentingan, hal ini merupakan

\footnotetext{
${ }^{23}$ Nur Pujayanti dan Harry Soeskandi, Pelaku Persekusi dan Tindakan Main Hakim Sendiri, Jurnal Mimbar Keadilan, Vol. 14 No. 28, Januari 2018 (Surabaya: Laboratorium Fakultas Hukum Untag, 2018), 241.

${ }^{24}$ Nur Pujayanti, Pertanggungjawaban Pidana Pelaku Persekusi, Skripsi, Surabaya Fakultas Hukum Untag, 2018, 44, http://repository.untag-sby.ac.id/390/6/JURNAL.pdf, http://repository.untagsby.ac.id/390/6/JURNAL.pdf, 17.

${ }^{25}$ https://kbbi.kemdikbud.go.id/entri/Main\%20hakim\%20sendiri, diakses pada tanggal 20 Mei 2019.
} 
pelaksanaan sanksi oleh perorangan. ${ }^{26}$ Sekedar perbandingan, dalam bahasa Inggris istilah main hakim sendiri dikenal dengan istilah vigilantism yang oleh Kamus Oxford diartikan sebagai law enforcement undertaken without legal authority by a selfappointed group of people (penegakan hukum yang dilakukan tanpa otoritas hukum oleh sekelompok orang yang ditunjuk sendiri). ${ }^{27}$

Pada bulan Juni 2017, berdasarkan pola kasus persekusi yang telah terjadi di Indonesia, Kabag Penum Divisi Humas Polri saat itu, Kombes Martinus Sitompul, mengatakan bahwa ada 4 macam proses hukum yang dapat menjerat pelaku persekusi. Pertama, memasuki rumah atau kantor tanpa seizin pemiliknya yang kemudian tidak diharapkan kehadirannya. Dijerat dengan Pasal 167 ayat 1 KUHP dengan ancaman hukuman 1 tahun penjara. Kedua, melakukan tindakan pemaksaan. Dijerat Pasal 335 KUHP dengan ancaman hukumannya 5 tahun penjara. Ketiga, melakukan penculikan. Diancam dengan pasal 328 KUHP dengan ancaman maksimal penjara 12 tahun. Keempat, melakukan penganiayaan. Dijerat Pasal 351 KUHP dengan hukuman 2 tahun penjara. Jika dilakukan bersama-sama maka dianggap pengeroyokan dan dijerat Pasal 170 KHUP dengan ancaman hukuman 5 tahun penjara. ${ }^{28}$

Dari penjelasan ini dapat disimpulkan bahwa unsur pidana dalam tindakan persekusi yang paling sering dilakukan ada 5: (1) memasuki rumah orang lain tanpa izin, (2) pemaksaan, (3) penculikan, (4) penganiayaan, dan (5) pengeroyokan.

\section{PERSEKUSI DALAM TINJAUAN FIQH JINAYAH.}

Persekusi dalam bahasan Arab diterjemahkan dengan kata iḍtihād (إضْطِهَاد)). Masdar (kata benda). Diartikan sebagai [tindakan] melampaui batas [dalam] kekuasaan dan perlakuan paksa, sewenang-wenang, melanggar prinsip-prinsip konstitusional, terutama perlindungan Hak Asasi Manusia. ${ }^{29}$ Diartikan pula sebagai penindasan atau pemaksaan. Sementara memersekusi (إضُطَهَ) diartikan dengan memperlakukan dengan

\footnotetext{
${ }^{26}$ Agen Sindikat, Kamus Hukum Terlengkap - 11.000 istilah bahasa Inggris \& Belanda, file PDF diunduh dari https://www.academia.edu/16083005/Kamus_Hukum_Terlengkap_11.000_istilah_bahasa_Inggris_and_Belanda?auto=download, diakses pada tanggal 20 Mei 2019.

${ }^{27} \mathrm{https}: / /$ www.lexico.com/en/definition/vigilantism, diakses pada tanggal 19 Mei 2019.

28 https://kumparan.com/kumparannews/polisi-ada-empat-jeratan-hukum-untuk-pelaku-persekusi, diakses pada tanggal 20 Mei 2019.

${ }^{29} \mathrm{https}: / /$ www.almaany.com/ar/dict/ar-ar/اضطهاد/, diakses pada tanggal 21 Mei 2019.
} 
kasar; memaksa dan menganiaya; menyakiti.${ }^{30}$ Definisi pertama tampaknya mengadopsi dari konsep persekusi sebagai sebuah kejahatan terhadap kemanusiaan menurut hukum internasional. Jika demikian, term idthihaddsebagai salah satu bentuk tindak pidana (jarimah) merupakan term baru dan tidak dikenal dalam fiqh jinayah.

Sejauh ini, dari penelusuran penulis terhadap sumber-sumber berbahasa Arab tidak ditemukan satupun tulisan yang menjelaskan idthihadddalam konteks fiqh jinayah atau hukum pidana islam. Idthihaddselalu dijelaskan dalam konteks hukum internasional tentang kejahatan terhadap kemanusiaan. Kejahatan terhadap Hak Asasi Manusia. ${ }^{31}$ Dengan demikian persekusi yang diartikan dengan idthihaddbukanlah tindak pidana biasa. Ia adalah tindak pidana luar biasa yang memerlukan kajian mendalam. Meskipun dalam batas tertentu bisa dijelaskan dengan pendekatan jarimah al-baghy (pemberontakan). Ini jika konteksnya konflik internal, dalam negeri. Lain hal jika konteksnya antar negara. Oleh karena itu pembahasan selanjutnya akan dibatasi pada bahwa persekusi atau idthihadddi sini dalam pengertian tindakan main hakim sendiri (eigenrechting) yang di dalamnya bisa mencakup berbagai macam tindak pidana biasa. Tergant ung perbuatan apa saja yang telah dilakukan pelaku.

Dalam fiqh jinayah tindak pidana disebut jarimah. Menurut Imam Al Mawardi, jarimah ialah perbuatan yang dilarang oleh syara' yang diancam oleh allah dengan hukuman hadddan ta'zir. $^{32}$ Dalam terminologi hukum pidana di Indonesia jarimah sama dengan tindak pidana atau delik.

Mayoritas ulama kemudian membagi jarimah ke dalam 3 kategori. Ketiga kategori itu ialah: (1) Jarimah hudud, (2) Jarimah qisas/ diat, (3) Jarimah ta'zir. Pembagian ini paling moderat dan banyak dianut meskipun ada sebagian kecil ulama membaginya menjadi 2 saja menjadi hanya jarimah hudud dan ta'zir saja dengan

\footnotetext{
30 Ibid.

${ }^{31}$ Lihat misalnya artikel Nawal Ahmed Saro Al Khalidi dari Universitas Nahrain Iraq tahun 2013, Jarimah Al-IdthihaddFi Daui Ahkam An-Nizam Al-Asasiy Li Al-Mahkamah Al-Jinaiy Ad-Dauliyah (Kejahatan Penganiayaan Berdasarkan Ketentuan Statuta Mahkamah Pidana Internasional) di http://nahrainuniv.edu.iq/ar/node/5312; Artikel Ala' Abd Al-Wahid, Jarimah IdthihaddAl-Aqalliyat (Tindak Pidana Persekusi Terhadap Minoritas) di https://iasj.net/iasj?func=fulltext\&aId=150998; Tulisan Amal Abd Al-Hadi Mas'ud, Jarimah Al-IdthihaddFi Al-Mawasiq Ad-Dauliyah (Kejahatan Penganiayaan pada Konvensi Internasional) di https://www.dampress.net/mobile/?page=show_det\&category_id=48\&id=52345\&lang=, diakses pada tanggal 21 Mei 2019.

${ }^{32}$ Ahmad Wardi Muslich, Hukum Pidana Islam (Jakarta: Sinar Grafika, 2016), ix.
} 
argumen bahwa jarimah qisas/ diat hakikatnya masuk dalam hudud karena mekanismenya diatur eksplisit dalam nas. Ada pula yang membagi menjadi 4. Pengategorian ini sama dengan 3 kategori dengan menambahkan satu jarimah lagi yaitu jarimah kaffarat.

Jarimah hudud ialah jarimah yang diancam dengan sanksi had. Sementara sanksi hadd ialah sanksi yang telah ditentukan dan diatur oleh syara' dan merupakan hak Allah. Diatur di sini berarti telah secara jelas termaktub di dalam al-Qur'an atau as-Sunnah. Pengaturan itu meliputi jenis tindak pidana dan hukumannya serta mekanisme pemidanaannya. Jarimah qisas/diat ialah jarimah yang diancam dengan hukuman qisas atau diat. Jarimah ta'zir ialah segala bentuk jarimah yang bukan tergolong dua jarimah tersebut. Jarimah ta'zir ini merupakan jarimah yang paling banyak cakupannya karena jarimah inilah yang mekanisme pengaturannya diserahkan kepada ulil amri (pemerintah). Nash tidak mengatur atau mengatur tapi tidak tegas tentang detil at urannya. Berbeda dengan dua macam jarimah pertama. Jarimah hudud dan qisas/ diat secara tegas diatur dalam nash oleh syari'. Manusia tidak boleh menambah atau mengurangi ketentuan yang telah ada.

Jarimah hudud terdiri dari 7 tindak pidana: perzinaan (zina), tuduhan perzinaan (qadzaf), pencurian (sariqah), minum minuman keras (syur bal khamr), perampokan (hirabah; qathi' at thariq), pemberontakan (baghy), dan murtad (riddah). Jarimah qisas/ diat terdiri dari 2 tindak pidana: pembunuhan (qatI) dan penganiayaan (jurh). Sementara tindak pidana yang tercakup jarimah ta'zir hampir tak terbatas jumlahnya. Mencakup tindak pidana hudud dan qisas/ diat yang tidak terpenuhi syarat-rukunnya (unsur pidananya) dan semua tindak pidana atau pelanggaran yang tidak diatur secara tegas dan jelas oleh nash.

Berdasarkan unsur pidana yang ada pada tindakan persekusi dapat dipahami bahwa apa yang disebut persekusi sesungguhnya bukanlah suatu tindak pidana tunggal. Dalam satu tindakan persekusi dapat terdiri dari beberapa tindak pidana. Sebagaimana dijelaskan di muka bahwa unsur pidana dalam persekusi setidaknya ada 5 yaitu: (1) memasuki rumah orang lain tanpa izin, (2) pemaksaan, (3) penculikan, (4) penganiayaan, dan (5) pengeroyokan maka dalam perspektif fiqh jinayah jarimah yang dilakukan juga 
tidak tunggal. Masing-masing unsur tindak pidana dalam persekusi dapat tergolong jarimah-jarimah berikut:

1. Penganiayaan (Jurh).

Ahmad Wardi Muslich mengutip Abdul Qadir Audah mendefinisikan penganiayaan sebagai setiap perbuatan menyakiti orang lain yang mengenai badannya tapi tidak sampai menghilangkan nyawanya. ${ }^{33}$ Penganiayaan dalam pengertian ini ialah penganiayaan fisik (badan; jasmani). Dengan begitu penganiayaan verbal tidak tergolong jarimah ini sehingga pengaturannya diat ur dalam jarimah ta'zir. Penganiayaan fisik di sini dapat berupa:

a. Perusakan atas anggota tubuh (athraf) atau bagian lain yang dianggap bagian dari tubuh dengan cara memotong atau melukai.

b. Pelukaan pada bagian muka dan kepala (syajjaj).

c. Pelukaan pada bagian tubuh yang tidak tergolong muka, wajah dan athraf. Disebut jirah. Bagian tubuh dimaksud terbatas pada leher, dada, perut hingga batas pinggul.

d. Penghilangan fungsi anggota tubuh, seperti pendengaran, penglihatan, dan fungsi otot.

e. Pemukulan ringan. Yaitu penganiayaan yang tidak mengakibatkan luka dan hilangnya fungsi anggota tubuh. Akibat dari perbuatan ini biasanya berupa memar, rasa sakit, dan sejenisnya. Menurut Abu Hanifah, pemukulan ringan ini tergolong jarimah ta'zir.

Penganiayaan jika dilakukan lebih dari satu orang disebut pengeroyokan. Jadi, pengeroyokan tergolong penganiayaan. Pengaturannya diatur dalam bab turut serta berbuat pidana (isytirak fi al jaraim). Tindakan penganiayaan maupun pengeroyokan ini diancam dengan sanksi qisas (sebagai hukuman pokok) dan diat atau ta'zir (keduanya sebagai hukuman pengganti).

\section{Perampokan (Hirabah)}

Menurut Nurul Irfan hirabah ialah kekerasan yang dilakukan seseorang atau sekelompok orang kepada pihak lain, baik dilakukan di dalam rumah maupun di luar rumah, untuk menguasai harta orang lain atau membunuh korban untuk menakut-

\footnotetext{
33 Ibid. 179.
} 
nakuti. ${ }^{34}$ Cakupan makna membunuh untuk menakut-nakuti di sini tidak hanya membunuh. Perbuatan lain dengan tujuan menakut-nakuti termasuk dalam makna ini, seperti gertakan, ancaman, kecaman, kekerasan, merakit dan meledakkan bom (teror) dan penculikan ${ }^{35}$. Jadi makna jarimah hirabah (perampokan) lebih luas dalam fiqh jinayah daripada apa yang kita kenal dalam hukum pidana konvensional di Indonesia.

Istilah lain untuk hirabahialah qat' at-thariq(pembegalan). Sekali lagi maknanya akan lebih luas dibanding yang kita kenal dalam hukum pidana konvensional. Sayyid Sabiq mendefinisikan qat' at-thariq sebagai Sekelompok manusia yang membuat keonaran, pertumpahan darah, merampas harta, kehormatan, tatanan, serta membuat kekacauan di muka bumi. ${ }^{36}$

Sanksi pidana untuk jarimah ini beragam sesuai dengan unsur pidana yang ditimbulkannya. Ulama umumnya membagi unsur jarimah hirabah menjadi 4, yaitu:

a. Dilakukan di jalan umum atau di luar pemukiman korban

b. Dilakukan terang-terangan

c. Dengan kekerasan atau ancaman kekerasan

d. Unsur-unsur jarimah pencurian, seperti pemindahan barang yang bukan miliknya dan kesengajaan melakukan tindakan tersebut

Oleh karena itu sanksinya juga dikategorikan ke dalam 4 macam sanksi, yaitu:

1) Hukuman mati

2) Disalib

3) Dipotong tangan dan kakinya secara bersilang

4) Diasingkan (dipenjara. Mayoritas ulama menyatakan selama 1 tahun)

Keempat sanksi ini dilaksanakan keseluruhan sesuai dengan tindakannya, atau sesuai dengan 4 macam jarimah hirabah di atas, yaitu:

a. Membunuh korban tanpa mengambil harta, sanksinya hukuman mati

b. Membunuh dan merampas harta korban, sanksinya hukuman mati dan disalib

c. Merampas harta korban, sanksinya potong tangan dan kaki secara bersilang

\footnotetext{
${ }^{34}$ Nurul Irfan dan Masyrofah, Fiqh jinayah (Jakarta: Amzah. 2013), 127.

${ }^{35}$ Lihat Nurul Irfan dan Masyrofah, Fiqh jinayah ..., 127 dan Sayyid Sabiq, Fiqh Sunnah, Terj. Moh. Nabhan Husein, Jild 9 (Jakarta: Al Maarif, 1984), 175.

${ }^{36}$ Sayyid Sabiq, Fiqh Sunnah, ..., 175.
} 
d. Menakut-nakuti korban atau membuat keonaran, sanksinya diasingkan (dipenjara).

Dari sini jelas, bahwa pelaku persekusi yang melakukan pemaksaan dan penculikan dapat dikategorikan melakukan jarimah hirabah dengan sanksi sebagaimana tersebut di atas.

\section{Jarimah Ta'zir}

Sebagaimana dijelaskan bahwa Jarimah ta'zir ialah jarimah yang paling luas cakupannya. Berdasarkan dasar hukum penetapannya jarimah ta'zir dibagi menjadi 3: (1) Jarimah ta'zir yang berasal dari jarimah hudud dan qisas/ diat yang tidak terpenuhi syarat rukunnya, (2) Jarimah ta'zir yang disebut dalam nash tetapi tidak dijelaskan hukumannya, (3) Jarimah ta'zir yang jenis dan hukumannya tidak ditentukan oleh nas. Untuk jenis terakhir ini mekanisme pengaturannya dikembalikan kepada ulil amri. Berdasarkan pertimbangan maslahah ulil amri berhak mengaturnya.

Mengutip Abdul Aziz Amir, Ahmad Wardi Muslich membagi ta'zir ke dalam 6 kategori;

a. Jarimah ta'zir yang berkaitan dengan pembunuhan

b. Jarimah ta'zir yang berkaitan dengan pelukaan

c. Jarimah ta'zir yang berkaitan dengan kejahatan terhadap kehormatan dan kerusakan akhlak

d. Jarimah ta'zir yang berkaitan dengan harta

e. Jarimah ta'zir yang berkaitan dengan kemaslahatan individu

f. Jarimah ta'zir yang berkaitan dengan keamanan umum. ${ }^{37}$

Lebih jauh, Ahmad Wardi Muslich menerangkan bahwa jarimah ta'zir yang berkaitan dengan kemaslahatan individu dapat berupa kesaksian palsu, berbohong (keterangan palsu), menyakiti hewan, melanggar hak privacy orang lain seperti masuk rumah orang lain tanpa izin. ${ }^{38}$

Dari sini jelas, karena memasuki rumah orang lain tanpa izin merupakan jarimah ta'zir yang mekanisme pengaturannya dilakukan oleh ulil amri maka dalam konteks ini pelaku persekusi yang memasuki rumah orang lain tanpa izin dihukum dengan peraturan

\footnotetext{
${ }^{37}$ Ahmad Wardi Muslich, Hukum Pidana Islam ..., 255- 256.

${ }^{38}$ Ibid. 257.
} 
yang ditetapkan oleh ulil amri. Dalam konteks Indonesia, perbuatan ini tergolong tindak pidana yang diatur dalam KUHP. Maka sanksi yang tercantum dalam KUHP Pasal 167 ayat 1 KUHP dengan ancaman hukuman 1 tahun penjara sudah sesuai dengan prinsip fiqh jinayah.

\section{KESIMPULAN}

Persekusi menurut makna asalnya merupakan kejahatan berat yang berkaitan dengan hak asasi manusia. Bahkan beberapa bentuk tindakan persekusi tergolong sebagai genosida. Dalam perkembangannya, penggunaan kata perskusi di Indonesia terhadap kasus-kasus pemaksaan, penganiayaan, pengeroyokan yang marak terjadi tiga tahun terakhir ini dianggap kurang tepat dan terlalu berlebihan. Berdasarkan pola tindak pidana yang terjadi apa yang sebut sebagai persekusi sebenarnya adalah tindakan main hakim sendiri yang dalam tata hukum pidana di Indonesia telah dikenal dengan sebutan eigenrechting. Berdasarkan polanya pula, unsur pidana yang paling sering terjadi dalam tindakan main hakim sendiri (perskusi) ialah memasuki rumah orang lain tanpa izin, pemaksaan, penculikan, penganiayaan, dan pengeroyokan. Dalam tinjauan fiqh jinayah, tindak pidana ini juga tergolong dalam beberapa kategori jarimah. Tindak pidana pemaksaan dan penculikan tergolong ke dalam jarimah hirabah. Penganiayaan dan pengeroyokan tergolong ke dalam jairmah al-jurh. Sementara memasuki rumah orang lain tergolong jarimah ta'zir.

\section{DAFTAR PUSTAKA}

Ahmad Wardi Muslich, Hukum Pidana Islam (Jakarta: Sinar Grafika, 2016)

Iwan Setiawan, Kajian Yuridis Terhadap Persekusi, Jurnal Ilmiah Galuh Yustisi, Vol. 5

No. 2, September 2017 (Ciamis: Fakultas Hukum Universitas Galuh)

Nur Pujayanti dan Harry Soeskandi, Pelaku Persekusi dan Tindakan Main Hakim

Sendiri, Jurnal Mimbar Keadilan, Vol. 14 No. 28, Januari 2018 (Surabaya:

Laboratorium Fakultas Hukum Untag, 2018)

Nur Pujayanti, Pertanggungjawaban Pidana Pelaku Persekusi, Skripsi (Surabaya: Fakultas Hukum Untag, 2018)

Nurul Irfan dan Masyrofah, Fiqh jinayah (Jakarta: Amzah. 2013) 
Sayyid Sabiq, Fiqh Sunnah, Terj. Moh. Nabhan Husein, Jild 9 (Jakarta: Al Maarif, 1984) Aryojati Ardipandanto, Persekusi; Perspektif Demokrasi, Majalah Info Singkat, Pemerintahan Dalam Negeri, Vol. IX, No. 11, Juni 2017 (Jakarta: Pusat Penelitian Badan Keahlian DPR RI, 2017)

Trias Palupi Kurnianingrum, Pengertian Persekusi dari Perspektif Hukum, Majalah Info Singkat, Hukum, Vol. IX, No. 24, Desember 2017 (Jakarta: Pusat Penelitian Badan Keahlian DPR RI, 2017)

Agen Sindikat, Kamus Hukum Terlengkap - 11.000 istilah bahasa Inggris \& Belanda, file PDF diunduh dari https://www.academia.edu/16083005/Kamus_Hukum_Terlengkap_11.000 istilah bahasa Inggris and Belanda?auto=download

Ala' Abd Al-Wahid, Jarimah IdthihaddAl-Aqalliyat di https://iasj.net/iasj?func=fulltext\&aId=150998

Amal Abd Al-Hadi Mas'ud, Jarimah Al-IdthihaddFi Al-Mawasiq Ad-Dauliyah di https://www.dampress.net/mobile/?page=show_det\&category_id=48\&id=5234 $5 \&$ lang=

Nawal Ahmed Saro Al Khalidi dari Universitas Nahrain Iraq tahun 2013, Jarimah AlIdthihaddFi Daui Ahkam An-Nizam Al-Asasiy Li Al-Mahkamah Al-Jinaiy AdDauliyah di http://nahrainuniv.edu.iq/ar/node/5312

http://legal.un.org

http://www.icty.org

https://kbbi.kemdikbud.go.id

https://kumparan.com

https://www.almaany.com

https://www.ldoceonline.com

https://www.lexico.com

https://www.merriam-webster.com

https://www.un.org

https://ylbhi.or.id

http://repository.untag-sby.ac.id 